\title{
High Solids Consolidated Incinerator Facility (CIF) Wastes Stabilization with Ceramicrete and Super Cement
}

by

B. W. Walker

Westinghouse Savannah River Company

Savannah River Site

Aiken, South Carolina 29808

\section{RECRIVED \\ SEP 271999 \\ OS $T_{1}$}

DOE Contract No. DE-AC09-96SR18500

This paper was prepared in connection with work done under the above contract number with the U.S.

Department of Energy. By acceptance of this paper, the publisher and/or recipient acknowledges the U.S. Government's right to retain a nonexclusive, royalty-free license in and to any copyright covering this paper, along with the right to reproduce and to authorize others to reproduce all or part of the copyrighted paper. 


\section{DISCLAIMER}

This report was prepared as an account of work sponsored by an agency of the United States Government. Neither the United.States Government nor any agency thereof, nor any of their employees, makes any warranty, express or implied, or assumes any legal liability or responsibility for the accuracy, completeness, or usefulness of any information, apparatus, product, or process disclosed, or represents that its use would not infringe privately owned rights. Reference herein to any specific commercial product, process, or service by trade name, trademark, manufacturer, or otherwise does not necessarily constitute or imply its endorsement, recommendation, or favoring by the United States Government or any agency thereof. The views and opinions of authors expressed herein do not necessarily state or reflect those of the United States Government or any agency thereof.

This report has been reproduced directly from the best available copy.

Available to DOE and DOE contractors from the Office of Scientific and Technical Information, P.O. Box 62, Oak Ridge, TN 37831; prices available from (615) 576-8401.

Available to the public from the National Technical Information Service, U.S. Department of Commerce, 5285 Port Royal Road, Springfield, VA 22161. 


\section{DISCLAIMER}

Portions of this document may be illegible in electronic image products. Images are produced from the best available original document. 
WSRC-TR-99-00182

Revision 0

Keywords: Solidification, Waste Treatment, Magnesium Potassium Phosphate hydrate, Slag Cement

Retention: Permanent

HIGH SOLIDS CONSOLIDATED INCINERATOR FACILITY (CIF) WASTES STABILIZATION WITH CERAMICRETE AND SUPER CEMENT (U)

\author{
JUNE 1, 1999
}

B. W. Walker, $773-43 \mathrm{~A}$

Savannah River Technology Center

Westinghouse Savannah River Company

Aiken, SC 29808

Prepared for the Department of Energy

Mixed Waste Focus Area

Technical Task Plan SR1-8-MW-44 
0

Review and Approvals

Authors

B.W. Walker

B.W. Walker

$6-1-99$

Date

Gewnence $O_{i}$

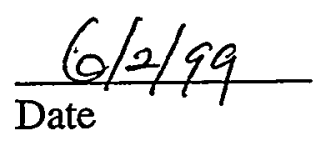

Level 4 Manager

W.B. Van feet

W.B. Van Pelt

$6 / 2 / 99$

Date

Level 3 Manager

heston

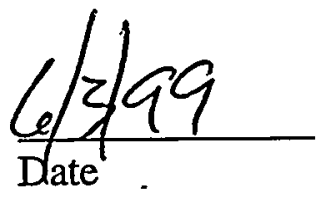

W.E. Stevens 


\section{TABLE OF CONTENTS}

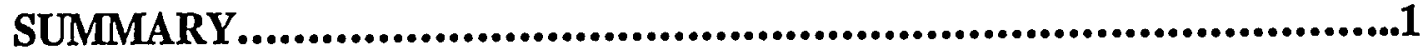

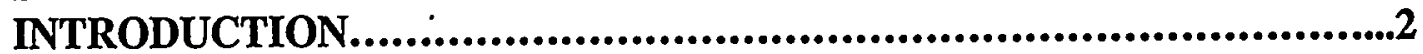

EXPERIMENTAL

Waste Form Acceptance Criteria..............................................3

High Solids Off gas Scrubber Solution Characterization...................4

High Solids Ash Characterization...............................................44

Preparation of Ceramicrete ${ }^{\mathrm{TM}}$ Waste Forms..................................5

Preparation of Super Cement ${ }^{\mathrm{TM}}$ Waste Forms..............................6

RESULTS

Freshly Prepared Waste Form Results.......................................8

Cured Waste Form Results..................................................9

Scanning Electroscopy and X-ray diffraction Results......................11

Permeability Results.............................................................13

Leaching Results..............................................................15

Waste Loadings Results....................................................17

CONCLUSIONS...................................................................19

QUALITY ASSURANCE........................................................21

ACKNOWLEDGEMENTS...................................................21

TABLES

Table I. Acceptance Criteria for Freshly Prepared Waste Forms .......3

Table II. Acceptance Criteria for Cured Waste Forms.....................3

Table III. Scrubber Solution (Blowdown) Characterization................4

Table IV. High Solids Ash Characterization.................................4

Table V. Ceramicrete ${ }^{\mathrm{TM}}$ Test Matrix.........................................5

Table VI. Super Cement ${ }^{\mathrm{TM}}$ Test Matrix......................................7

Table VII. Super Cement Formula Modification............................8

Table VIII. High Solids Ceramicrete ${ }^{\mathrm{TM}}$ Freshly Prepared Waste

Form Criteria Evaluations..................................................8

Table IX. High Solids Super Cement ${ }^{\mathrm{TM}}$ Freshly Prepared Waste

Form Criteria Evaluations.................................................9

Table X. High Solids Ceramicrete ${ }^{\mathrm{TM}}$ Cured Waste Form Criteria

Evaluation.................................................................. 10

Table XI. High Solids Super Cement ${ }^{\mathrm{TM}}$ Cured Waste Form Criteria

Evaluation..................................................................... 11

Table XII. Waste Form Permeability...................................... 13

Table XIII. TCLP Results for Ceramicrete ${ }^{\mathrm{TM}}$ Waste Forms..............16

Table XIV. TCLP Results for Super Cement ${ }^{\mathrm{TM}}$ Waste Forms...........16

Table XV. Ceramicrete ${ }^{T M}$ Waste Loadings.................................17

Table XVI. Super Cement ${ }^{\mathrm{TM}}$ Waste Loadings...............................18

Table XVII. Waste Form Densities..........................................19 


\section{FIGURES}

Figure I. Ash and Scrubber Solution Ceramicrete ${ }^{\mathrm{TM}}$ Waste Form.....10

Figure II. Permeameter manufactured by ELE.........................14 APPENDICES

Appendix 1. Waste Loading Calculations for Portland Cement........A-1 Appendix 2. Permeabililty Calculations for Waste Forms..............A-2 Appendix 3. Ceramicrete ${ }^{\text {TM }}$ Ash and Blowdown Waste Form XRD...A-3 


\section{SUMMARY}

The Consolidated Incinerator Facility (CIF) at the Department of Energy Savannah River Site (SRS) burns low level radioactive and mixed waste. Ash and scrubber system waste streams are generated during the incineration process and are currently solidified with Portland cement. Magnesium Phosphate Ceramic $\left(\right.$ Ceramicrete ${ }^{\mathrm{TM}}$ ) and Slag Cement (Super Cement ${ }^{\mathrm{TM}}$ ) technologies were tested to evaluate their effectiveness to stabilize High Solids ash and scrubber solution (blowdown) waste streams, which are generated from incineration of radioactive diatomaceous earth filters. Waste Acceptance Criteria (WAC) used to evaluate solid waste forms generated are compressive strength, leaching of hazardous metals, bleed water, set time, and permeability. These criteria were used to generate the following summary statements.

- Ceramicrete ${ }^{\mathrm{TM}}$ solid waste forms made with scrubber solution, ash, and a combination of scrubber solution and ash meet the Waste Acceptance Criteria (WAC) of compressive strength $>500 \mathrm{psi}$, leaching levels for arsenic, mercury, barium, chromium, lead, selenium, silver, and cadmium less than the 40 CFR 268.48 Universal Treatment Standards, no bleed water after 24 hours, and a set time of less than 24 hours.

- The Ceramicrete ${ }^{\mathrm{TM}}$ blank, which should have the best permeability of the Ceramicrete $^{\mathrm{TM}}$ samples prepared, had a permeability of $1 \times 10^{-4} \mathrm{~cm} / \mathrm{s}$ which does not meet the WAC requirement of $10^{-8} \mathrm{~cm} / \mathrm{s}$.

- After curing for 3 to 4 months Ceramicrete ${ }^{\mathrm{TM}}$ samples made with scrubber solution and ash exhibited cracking and visible crystal formation. The deterioration was caused by the formation of potassium chloride, sodium phosphate hydrate, and sodium calcium sulfate formation. Ceramicrete ${ }^{\mathrm{TM}}$ is not recommended for sodium chloride wastes because of the cracking and crystal formation observed with waste forms made with ash and scrubber solution.

- Super Cement ${ }^{\mathrm{TM}}$ solid waste forms made with scrubber solution and ash/scrubber solution combinations met the compressive strength, leaching, bleed water, permeability, and setting requirements of the WAC.

- Super Cement ${ }^{\mathrm{TM}}$ solid waste forms made with only ash passed all WAC requirements except the setting requirement. Modification of the formulation by adding calcium hydroxide or Portland cement resulted in a waste form that meets the setting requirement.

- Ash waste loadings up to $50 \%$ by weight were achieved with Ceramicrete ${ }^{\mathrm{TM}}$ waste forms and up to $66.7 \mathrm{wt} \%$ were achieved with Super Cement ${ }^{\mathrm{TM}}$ waste forms which are greater than current plant Portland cement waste loadings of $31.8 \%$.

- Blowdown waste loadings up to 28 wt $\%$ were achieved with Ceramicrete ${ }^{\mathrm{TM}}$ waste forms and up to $43.1 \mathrm{wt} \%$ were achieved with Super Cement ${ }^{\mathrm{TM}}$ waste forms which 
are less than current plant Portland cement waste loadings of $46 \mathrm{wt} \%$. The waste loadings of blowdown waste forms for both Ceramicrete ${ }^{\mathrm{TM}}$ and Super Cement ${ }^{\mathrm{TM}}$ are actually greater than the plant waste loadings because samples in this study were concentrated up to 20 and $30 \mathrm{wt} \%$ total solids. The $46 \mathrm{wt} \%$ waste loading for the plant Portland cement is based on using blowdown solution with $10 \mathrm{wt} \%$ total solids because currently the plant has no equipment to concentrate the blowdown waste.

\section{INTRODUCTION}

High Solids ash and scrubber solution waste streams were generated at the incinerator facility at SRS by burning radioactive diatomaceous filter rolls which contained small amounts of uranium, and listed solvents ( $F$ and $U$ ). This report details solidification activities using selected Mixed Waste Focus Area (MWFA) technologies with the High Solids waste streams.

Solidification of a Low Solids ash and scrubber solution generated from incineration of a radioactive Purex waste containing small amounts of plutonium and other radionuclides will be covered in a final report due 9/30/99. Low Solids waste will be tested with Portland and Super Cement ${ }^{\mathrm{TM}}$ technologies since the Ceramicrete ${ }^{\mathrm{TM}}$ technology has permeability and waste form cracking problems.

Currently the waste solidification section of the incinerator uses Portland cement. SRS is modifying and upgrading the waste solidification part of the incinerator process to optimize solid waste form loadings, improve solid waste form characteristics, increase through put, and reduce equipment down time.

Ceramicrete $^{\mathrm{TM}}$ and Super Cement ${ }^{\mathrm{TM}}$ technologies were chosen as the best possible replacement solidification candidates for the waste streams generated by the SRS incinerator from a list of several suggested Mixed W.aste Focus Area technologies. These technologies were tested, evaluated, and compared to the current Portland cement technology being employed. Recommendation of a technology for replacement will depend on whether the technologies are superior to the current Portland cement technology in respect to meeting the WAC, have higher waste loadings, and are not prohibitively expensive in implementation or raw materials cost.

Ceramicrete $^{\mathrm{TM}}$ technology was developed at Argonne National Laboratory for the treatment of various low-level mixed wastes. ${ }^{1}$ Setting is the result of an acid-base reaction which occurs at ambient temperature according to the following reaction given in Equation $1 .^{2}$

$$
\mathrm{MgO}+\mathrm{KH}_{2} \mathrm{PO}_{4}+5 \mathrm{H}_{2} \mathrm{O} \rightarrow \mathrm{MgKPO}_{4} \cdot 6 \mathrm{H}_{2} \mathrm{O}
$$

Starting materials used in this study were prepared at Argonne National Laboratory specifically for this testing. The manufacture of the $\mathrm{MgO}$ was engineered to produce slow reaction with the $\mathrm{KH}_{2} \mathrm{PO}_{4}$. Ceramicrete ${ }^{\mathrm{TM}}$ is the mixture of $\mathrm{MgO}$ and 
$\mathrm{KH}_{2} \mathrm{PO}_{4}$ in stoichiometric quantities which when mixed with the stoichiometric amount of water will produce the hydrated product on the right side of Equation 1.

Super Cement ${ }^{\mathrm{TM}}$ technology uses a cement binder of alkali activated slag cement. The cement consists of glassy blast furnace slag, and additives for TCLP improvement, dispersion, and $\mathrm{pH}$ adjustment. In this study two types of Super Cement ${ }^{\mathrm{TM}}$ were used with different particle size. Since the Super Cement ${ }^{\mathrm{TM}}$ formulation information is proprietary, specific details will not be released in this report without clearance from the manufacturer, ADTECHS Corp./JGC Corp.

\section{EXPERIMENTAL}

Ceramicrete ${ }^{\mathrm{TM}}$ and Super Cement ${ }^{\mathrm{TM}}$ solid waste forms were made with scrubber solution, ash, and a combination of ash and scrubber solution. The waste forms were then cured for 28 days and tests performed to determine if waste acceptance criteria were met.

\section{Waste Form Acceptance Criteria}

Acceptance criteria for the solid waste forms which include leachability, bleed water, compression testing, and permeability are listed in Tables I, II. Waste loading, mixing properties, and data on whether waste forms meet acceptance criteria will be compared to the current Portland cement solidification technology now used at the SRS incinerator for solidification of waste.

Table I. Acceptance Criteria for Freshly Prepared Waste Forms

$\begin{array}{ll}\begin{array}{ll}\text { Property } \\ \text { Bleed water }\end{array} & \begin{array}{l}\text { Acceptance Criteria } \\ \text { O volume after 24 hours } \\ \text { Set time }\end{array} \\ \begin{array}{ll}\text { Mixability } \\ \text { Processibility }\end{array} & \begin{array}{l}\text { Low viscosity } 3 \text { days (shorter } \\ \text { Minimal number of compon }\end{array} \\ \text { Table II. Acceptance Criteria for Cured Waste Forms } \\ \text { Property } & \text { Acceptance Criteria } \\ \text { Compressive Strength } & >500 \mathrm{psi} \\ \text { Permeability } & <10^{-8} \mathrm{~cm} / \mathrm{s} \\ \text { RCRA metal } & \text { Regulatory Limit (ppm) } \\ \text { As } & 5 \\ \mathrm{Hg} & 0.025 \\ \mathrm{Ba} & 7 \\ \mathrm{Cr} & 0.86 \\ \mathrm{~Pb} & 0.37 \\ \mathrm{Se} & 0.16 \\ \mathrm{Ag} & 0.3 \\ \mathrm{Cd} & 0.69\end{array}$


Note: RCRA metal regulatory leaching ppm limits are from 40CFR 268.48 Universal Treatment Standards ${ }^{3}$

\section{High Solids Off Gas Scrubber Solution (Blowdown) Characterization}

Characterization of the incinerator blowdown is given in Table III. The quench system is operated to produce blowdown containing close to $10 \%$ total solids. The suspended solids of the blowdown used in this study were $1.5 \%$ and contained mostly $\mathrm{SiO}_{2}$ and $\mathrm{Zn}(\mathrm{OH})_{2}$. Dissolved solids results from analyses on plant samples were $8.2 \%$ and are usually $\mathrm{NaCl}$ and $\mathrm{Na}_{2} \mathrm{SO}_{4}$. The $\mathrm{pH}$ of the blowdown was 8.77 and the water content $90.3 \%$.

Table III. Scrubber Solution (Blowdown) Characterization

\begin{tabular}{lc} 
Component & (mg/liter) \\
\hline Aluminum & 541.5 \\
Calcium & 600.3 \\
Iron & 545.3 \\
Magnesium & 178.0 \\
Sodium & 32126.8 \\
Fluoride & 639.0 \\
Formate & $<10.0$ \\
Chloride & $19,618.0$ \\
Nitrite & 230.0 \\
Nitrate & 274.0 \\
Phosphate & 260.0 \\
Sulfate & 40247.0 \\
Oxalate & $<10.0$
\end{tabular}

\section{High Solids Ash Characterization}

High Solids ash characterization of the incinerator ash is given in Table IV.

Table IV. High Solids Ash Characterization

Based on X-ray diffraction the ash contained :

Cristobalite; $\mathrm{SiO}_{2}$ Silicon oxide; $\mathrm{SiO}_{2}$ Anorthoclase; $(\mathrm{NaK})\left(\mathrm{AlSi}_{3} \mathrm{O}_{8}\right)$ Magnetite; $\mathrm{Fe}_{3} \mathrm{O}_{4}$ Hematite; $\mathrm{Fe}_{2} \mathrm{O}_{3}$.

The ash was wet quenched and contained $45+/-15 \%$ quench water. Ash used in this study was drained of excess water which resulted in a water content of about $25 \%$. The $\mathrm{pH}$ of the water in contact with the ash was 10.55 . 


\section{Preparation of Ceramicrete ${ }^{\mathrm{TM}}$ Waste Forms}

Ceramicrete ${ }^{\mathrm{TM}}$ waste forms were prepared by reacting calcined magnesium oxide with potassium phosphate under aqueous conditions and mixing with either the ash or scrubber solution or mixtures of ash and scrubber solution for 20 minutes then pouring into a plastic mold to set. The binder contains $\mathrm{MgO}$ and $\mathrm{KH}_{2} \mathrm{PO}_{4}$ in a mixture ratio of 9.4 grams to 32.0 grams respectively. During mixing, 0.08 grams of $\mathrm{SnCl}_{2}$ and 0.04 grams of $\mathrm{Na}_{2} \mathrm{~S}$ were added for 100 grams of waste form generated to improve RCRA metal leaching characteristics. This process was repeated with different proportions of ash, scrubber solution, and combinations of ash and scrubber solution. The test matrix of waste forms composition is given in Table V.

The scrubber solution was evaporated before solidification to achieve higher salt waste loadings (up to $30 \mathrm{wt} \%$ total solids) in the waste form while maintaining the same amount of water. The samples were cured in sealed containers for 28 days. After removing the waste form from the molds the samples were divided for compressive strength and analytical testing.

Table V. Ceramicrete ${ }^{\mathrm{TM}}$ Test Matrix

\begin{tabular}{|c|c|c|c|c|c|c|c|}
\hline $\begin{array}{l}\text { Sample } \\
\text { Number }\end{array}$ & $\begin{array}{l}\text { Ash } \\
W t \\
\text { (g) }\end{array}$ & $\begin{array}{l}\text { Added } \\
\mathrm{H}_{2} \mathrm{O} \\
\mathrm{Wt} \\
(\mathrm{g})\end{array}$ & $\begin{array}{l}\text { Blow } \\
\text { down } \\
10 w t \% \\
\text { Solids(g) }\end{array}$ & $\begin{array}{l}\text { Blow } \\
\text { down } \\
20 \text { wt \% } \\
\text { Solids(g) }\end{array}$ & $\begin{array}{l}\text { Blow } \\
\text { down } \\
30 \text { wt \% } \\
\text { Solids(g) }\end{array}$ & $\begin{array}{l}\text { Binder } \\
\mathrm{Wt} \\
\text { (g) }\end{array}$ & $\begin{array}{l}\text { Class F } \\
\text { Fly ash } \\
\text { Wt } \\
(\mathrm{g})\end{array}$ \\
\hline 1 & 0 & 12.6 & 0 & 0 & 0 & 41.4 & 50 \\
\hline 2 & 0 & 0 & 10 & 0 & 0 & 71.2 & 0 \\
\hline 3 & 0 & 0 & 25 & 0 & 0 & 73.8 & 0 \\
\hline 4 & 0 & 0 & 0 & 36.1 & 0 & 93.8 & 0 \\
\hline 5 & 40 & 11.2 & 0 & 0 & 0 & 49.0 & 0 \\
\hline 6 & 50 & 6.5 & 0 & 0 & 0 & 43.5 & 0 \\
\hline 7 & 60 & 2.6 & 0 & 0 & 0 & 38.4 & 0 \\
\hline 8 & 50 & 12.6 & 0 & 0 & 0 & 49.4 & 0 \\
\hline 9 & 50 & 6.5 & 0 & 0 & 0 & 43.5 & 0 \\
\hline 10 & 16.5 & 0 & 25 & 0 & 0 & 66.4 & 0 \\
\hline 11 & 45 & 0 & 15 & 0 & 0 & 60.7 & 0 \\
\hline 12 & 48 & 0 & 0 & 16 & 0 & 55.6 & 0 \\
\hline 13 & 15 & 0 & 15 & 0 & 0 & 56.0 & 0 \\
\hline 14 & 6.7 & 0 & 33.3 & 0 & 0 & 74.2 & 0 \\
\hline 15 & 4.0 & 0 & 40.0 & 0 & 0 & 74.1 & 0 \\
\hline 16 & 7.0 & 0 & 35.0 & 0 & 0 & 66.5 & 0 \\
\hline 17 & 20 & 0 & 0 & 0 & 20 & 47.6 & 0 \\
\hline 18 & 30 & 0 & 0 & 0 & 10 & 63.3 & 0 \\
\hline 19 & 6.7 & 0 & 0 & 0 & 33.3 & 99.1 & 0 \\
\hline 20 & 6.7 & 0 & 0 & 33.3 & 0 & 111.6 & 0 \\
\hline
\end{tabular}


Notes for Table V:

1) Binder contains $\mathrm{MgO}$ and $\mathrm{KH}_{2} \mathrm{PO}_{4}$ mixture ratio of 9.4 grams to 32.0 grams. 2) .08 grams of $\mathrm{SnCl}_{2}$ and .04 grams of $\mathrm{Na}_{2} \mathrm{~S}$ were added during mixing for each 100 grams of waste form generated to improve RCRA metal leaching characteristics.

3) Sample \# 9 has no $\mathrm{SnCl}_{2}$ or $\mathrm{Na}_{2} \mathrm{~S}$

4) Total water content of the waste form = added water + BD water + ash water

\section{Preparation of Super Cement ${ }^{\mathrm{TM}}$ Waste Forms}

Super Cement ${ }^{\mathrm{TM}}$ waste forms were prepared according to Test Matrix VI. The water to cement ratio ranged from 0.5 to 1 . Details concerning hardening, dispersing, and TMT15 agents are proprietary and will not be disclosed without ADTECHS Corp./JGC Corp. permission. Because the reagent details are proprietary the weight of Super Cement ${ }^{\mathrm{TM}}$ and other additives are not listed in Test Matrix V. However, the total sample weight is listed so that the waste weight per cent can be easily seen.

Sodium sulfide and an organic reagent (TMT15) were added to the initial mix to improve leaching characteristics for toxic metals such as $\mathrm{As}, \mathrm{Se}, \mathrm{Cr}$, and $\mathrm{Pb}$. A dispersing reagent was added to samples containing ash to aid in dispersing the binder particles and fine ash particles.

Super Cement ${ }^{\mathrm{TM}}$ waste form ingredients were mixed for 10 minutes. The sequence of mixing is to:

1) add waste

2) add TMT15 and sodium sulfide

3) add dispersing agent

4) add hardening agent

5) add Super Cement ${ }^{\mathrm{TM}}$.

Two different kinds of Super Cement ${ }^{\mathrm{TM}}$ were used in this study (American and Japanese Super Cement ${ }^{\mathrm{TM}}$ ). The American Super Cement ${ }^{\mathrm{TM}}$ had to be blended by adding powdered silicon oxide to blast furnace slag produced by KOCH Chemical Company. The Super Cement ${ }^{\mathrm{TM}}$ from Japan by ADTECHS Corp./JGC Corp. does not need blending because it already contained silicon oxide. 
Table VI. Super Cement ${ }^{\mathrm{TM}}$ Test Matrix

\begin{tabular}{|c|c|c|c|c|c|c|}
\hline Sample & $\begin{array}{l}\text { SRS } \\
\text { Ash } \\
\text { Wt }\end{array}$ & $\begin{array}{l}\text { Added } \\
\mathrm{H} 2 \mathrm{O} \\
\mathrm{Wt}\end{array}$ & $\begin{array}{l}\text { Blow } \\
\text { down } \\
10 w t \%\end{array}$ & $\begin{array}{l}\text { Blow } \\
\text { down } \\
20 \text { wt } \%\end{array}$ & $\begin{array}{l}\text { Blow } \\
\text { down } \\
30 w t \%\end{array}$ & $\begin{array}{l}\text { Total } \\
\text { Sample } \\
\mathrm{Wt}\end{array}$ \\
\hline Number & (g) & (g) & Solids (g) & Solids (g) & Solids (g) & $(\mathrm{g})$ \\
\hline 21 & 0 & 40.0 & 0 & 0 & 0 & 109.6 \\
\hline 22 & 0 & 0 & 41.5 & 0 & 0 & 106 \\
\hline 23 & 0 & 0 & 40.0 & 0 & 0 & 101.9 \\
\hline 24 & 0 & 0 & 0 & 42.0 & 0 & 104.2 \\
\hline 25 & 0 & 0 & 0 & 40.0 & 0 & 92.8 \\
\hline 26 & 0 & 0 & 0 & 0 & 42.1 & 103.1 \\
\hline 27 & 40 & 10.0 & 0 & 0 & 0 & 112 \\
\hline 28 & 60 & 0 & 0 & 0 & 0 & 113.4 \\
\hline 29 & 60 & 0 & 0 & 0 & 0 & 98.1 \\
\hline 30 & 40.0 & 0 & 0 & 0 & 0 & 60 \\
\hline 31 & 40.0 & 0 & 0 & 0 & 0 & 77.8 \\
\hline 32 & 40.0 & 0 & 0 & 0 & 0 & 99 \\
\hline 33 & 20.0 & 0 & 20.0 & 0 & 0 & 103.1 \\
\hline 34 & 30.0 & 0 & 10.0 & 0 & 0 & 94.3 \\
\hline 35 & 6.7 & 0 & 33.3 & 0 & 0 & 103.6 \\
\hline 36 & 20 & 0 & 0 & 20 & 0 & 94.6 \\
\hline 37 & 30.0 & 0 & 0 & 10 & 0 & 92.5 \\
\hline 38 & 6.7 & 0 & 0 & 33.3 & 0 & 96.3 \\
\hline 39 & 20 & 0 & 0 & 0 & 20 & 92.3 \\
\hline 40 & 30 & 0 & 0 & 0 & 30 & 110.5 \\
\hline 41 & 6.7 & 0 & 0 & 0 & 33.3 & 97.2 \\
\hline
\end{tabular}

Note for Table VI:

All samples were made with American Super Cement $^{\mathrm{TM}}$ except for sample 39 and 40. 
When none of the Super Cement ${ }^{\mathrm{TM}}$ solid waste forms made with ash set in 24 hours the formula was modified as given in Table VII.

Table VII. Super Cement ${ }^{\mathrm{TM}}$ Formula Modification

\begin{tabular}{llllllll}
$\begin{array}{l}\text { Sample } \\
\text { Number }\end{array}$ & $\begin{array}{l}\mathrm{NaCl} \\
(\mathrm{g})\end{array}$ & $\begin{array}{l}\mathrm{Ca}(\mathrm{OH}) 2 \\
(\mathrm{~g})\end{array}$ & $\begin{array}{l}\text { P. Cem. } \\
(\mathrm{g})\end{array}$ & $\begin{array}{l}\text { S. Cem. } \\
(\mathrm{g})\end{array}$ & $\begin{array}{l}\text { Ash } \\
(\mathrm{g})\end{array}$ & $\begin{array}{l}\text { Water } \\
(\mathrm{g})\end{array}$ & $\begin{array}{l}\text { Waste Loading } \\
\mathrm{Wt} \%\end{array}$ \\
\hline 42 & 0 & 2.5 & 0 & 50 & 50 & 30.0 & 37.8 \\
43 & 0 & 12.5 & 0 & 40 & 50 & 34.3 & 36.6 \\
44 & 0 & 0 & 12.5 & 40 & 50 & 40.0 & 35.1 \\
45 & 7.6 & 0 & 0 & 45 & 50 & 24.6 & 39.3
\end{tabular}

Note: All samples in Table VII were made with Japanese type Super Cement ${ }^{\mathrm{TM}}$.

\section{RESULTS}

Freshly Prepared Waste Form Results

A substantial amount of bleed water was observed in Ceramicrete ${ }^{\mathrm{TM}}$ waste forms made with scrubber solution Samples 2,4 (Table V) but was absorbed after 24 hours of set time.

Table VIII. High Solids Ceramicrete ${ }^{\mathrm{TM}}$ Freshly Prepared Waste Form Criteria Evaluation

\begin{tabular}{lllll} 
Waste form Type & $\begin{array}{l}\text { Set Time } \\
\leq 1 \text { day }\end{array}$ & $\begin{array}{l}\text { Bleedwater } \\
\text { after } 24 \mathrm{hrs}\end{array}$ & $\begin{array}{l}\text { Good } \\
\text { Mixability }\end{array}$ & $\begin{array}{l}\text { Easily } \\
\text { Processed }\end{array}$ \\
\cline { 2 - 4 } Ash & yes & no & yes & yes \\
Scrubber solution & yes & no & yes & yes \\
Ash and scrubber & yes & no & yes & yes
\end{tabular}

solution

Super Cement ${ }^{\mathrm{TM}}$ solid waste forms made from only scrubber solution and a ash-scrubber solution combination using the original formulation set within 24 hours but waste forms made with ash using the original formulation did not. 
The formulation modification of adding enough calcium hydroxide to the ash so that the calcium hydroxide is $25 \mathrm{wt} \%$ of the ash and calcium hydroxide mixture then treating with Super Cement ${ }^{\mathrm{TM}}$ resulted in a waste form that set within time requirements. Use of only $5 \%$ by weight calcium hydroxide with ash and calcium hydroxide mixture and Super Cement ${ }^{\mathrm{TM}}$ treatment did not give a waste form that set within time requirements.

Formulation modification by adding Portland cement to the ash so the Portland cement is $25 \%$ by weight of the Portland Cement and ash mixture followed by Super Cement ${ }^{\mathrm{TM}}$ treatment also gave waste forms that set with time constraints. The modification of adding $25 \%$ by weight of $\mathrm{NaCl}$ in an ash and $\mathrm{NaCl}$ mixture then Super Cement ${ }^{\mathrm{TM}}$ treatment resulted in a waste form that did not set.

An overview of High Solids Super Cement ${ }^{\mathrm{TM}}$ Freshly Prepared Waste Forms is given in Table IX.

Table IX. High Solids Super Cement ${ }^{\mathrm{TM}}$ Freshly Prepared Waste Form Criteria Evaluation

\begin{tabular}{|c|c|c|c|c|}
\hline Waste form Type & $\begin{array}{l}\text { Set Time } \\
\leq 1 \text { day }\end{array}$ & $\begin{array}{l}\text { Bleedwater } \\
\text { after } 24 \text { hrs. }\end{array}$ & $\begin{array}{l}\text { Good } \\
\text { Mixability }\end{array}$ & $\begin{array}{l}\text { Easily } \\
\text { Processed }\end{array}$ \\
\hline$\overline{\text { Ash }}$ & no & no & yes & yes \\
\hline Scrubber solution & yes & no & yes & yes \\
\hline $\begin{array}{l}\text { Ash and scrubber } \\
\text { solution }\end{array}$ & yes & no & yes & yes \\
\hline modified Ash & yes & no & yes & yes \\
\hline
\end{tabular}

\section{Cured Waste Form Results}

Compressive strength estimates were determined after 28 days of curing time by using a Penetrometer for Concrete model \# HM-78 from the Gilson Company in Worthington, Ohio.

All Ceramicrete ${ }^{\mathrm{TM}}$ samples tested with the concrete penetrometer gave compressive strengths greater than $700 \mathrm{psi}$ which exceeds our specification criteria of $500 \mathrm{psi}$. After prolonged curing crystalline type structures and swelling were observed in waste forms made with both blowdown and SRS ash (See Figure 1). This swelling resulted in cracking which does not meet durability criteria. 


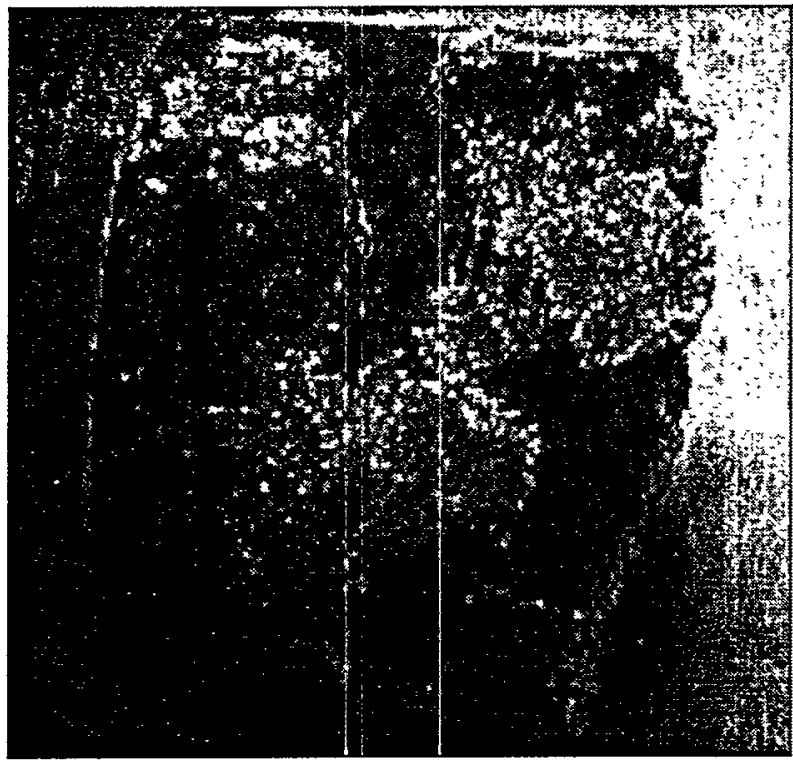

Figure 1. Ceramicrete ${ }^{\mathrm{TM}}$ waste form made with ash and scrubber solution

See Table X for an overview of Ceramicrete ${ }^{\text {TM }}$ Cured Waste Form Test Results.

Table X. High Solids Ceramicrete ${ }^{\mathrm{TM}}$ Cured Waste Form Criteria Evaluation

\begin{tabular}{|c|c|c|c|}
\hline form Type & $\begin{array}{l}>500 \mathrm{psi} \\
\text { Compressibility }\end{array}$ & $\begin{array}{l}<10^{-8} \mathrm{~cm} / \mathrm{s} \\
\text { permeability }\end{array}$ & $\begin{array}{l}\text { Leachability } \\
\text { limits met }\end{array}$ \\
\hline lank waste form & yes & no & not applicable \\
\hline Ash & yes & not tested & yes \\
\hline Scrubber solution & yes & not tested & yes \\
\hline Ash and scrubber & yes & not tested & yes \\
\hline
\end{tabular}
solution

Compressive strengths of Super Cement ${ }^{\mathrm{TM}}$ waste forms made with scrubber solutions and a combination of scrubber solutions and ash were $>700$ psi which meets acceptance criteria. Waste forms made with ash using the original formulation gave unacceptable compression results of $<500$ psi. 
WSRC-TR-99-00182

June 1,1999

Page 11 of 21

Table XI. High Solids Super Cement ${ }^{\mathrm{TM}}$ Cured Waste Form Criteria Evaluation

\begin{tabular}{|c|c|c|c|}
\hline Waste form Type & $\begin{array}{l}>500 \mathrm{psi} \\
\text { Compressibility }\end{array}$ & $\begin{array}{l}<10^{-8} \mathrm{~cm} / \mathrm{s} \\
\text { permeability }\end{array}$ & $\begin{array}{l}\text { Leachability } \\
\text { limits met }\end{array}$ \\
\hline Blank waste form & yes & yes & $\overline{\text { not applicable }}$ \\
\hline Ash & no & not tested & yes \\
\hline Scrubber solution & yes & not tested & yes \\
\hline $\begin{array}{l}\text { Ash and scrubber } \\
\text { solution }\end{array}$ & yes & not tested & yes \\
\hline Modified Ash & yes & not tested & not tested \\
\hline
\end{tabular}

Scanning Electron Microscopy and X-ray Diffraction Results

The microstructure of the ash and waste forms made from the High Solids ash and scrubber solution were examined by scanning electron microscopy (SEM). Qualitative elemental analyses of these materials was obtained by energy dispersive $\mathrm{X}$-ray analysis (EDX).

SEM of only the high solids ash indicates a very porous structure and EDX analyses shows the presence of $\mathrm{Si}, \mathrm{Fe}, \mathrm{Al}, \mathrm{Ca}$, and $\mathrm{K}$. SEM of the Ceramicrete ${ }^{\mathrm{TM}}$ waste forms revealed a matrix phase consisting of short needle shaped crystals of $\mathrm{MgKPO}_{4} \cdot 6 \mathrm{H}_{2} \mathrm{O}$ which were interlocked to form a solid coherent matrix. The needles are intergrown and the overall microstructure is relatively porous. The elemental profiles confirm the presence of sodium, sulfate, and chloride which could be distributed in pore spaces or the matrix of the waste form.

SEM micrographs of a Ceramicrete ${ }^{\mathrm{TM}}$ waste form containing ash and $30 \mathrm{wt} \%$ total solids scrubber solution displayed cracking, expansion, and crystal growth. $\mathrm{KCl}$ was detected in an elemental scan. Since the potassium was present as a component of the binder and the $\mathrm{Cl}$ was introduced from the waste, reaction between the cured binder, original binder components, and the scrubber solution has occurred. The sample structure is very porous and open. With prolonged curing there is more crystallization to a phase containing more potassium than in the fresh waste form. 
$\mathrm{X}$-ray diffraction analyses of the Ceramicrete ${ }^{\mathrm{TM}}$ waste forms reveals crystalline phases. Distinct peaks are seen for the binding magnesium potassium phosphate phase. MgO, which functions as a filler material in the matrix, also shows up as peaks in $\mathrm{X}$-ray diffraction patterns.

The Ceramicrete ${ }^{\mathrm{TM}}$ matrix when prepared with tap water is $\mathrm{KMgPO}_{4} \cdot 6 \mathrm{H}_{2} \mathrm{O}$ with trace amounts of $\mathrm{MgO}$. When the same stoichiometrically proportional starting materials are mixed with High Solids scrubber solution an impure $(\mathrm{XK}) \mathrm{KMgPO}_{4}{ }^{\cdot} 6 \mathrm{H}_{2} \mathrm{O}$ phase and magnesium aluminum phosphate hydrate phase are formed. These phases were detected in X-ray diffraction patterns and in SEM/EDX elemental scans as struvite and montgomeryite. Struvite, $\mathrm{NH}_{4} \mathrm{MgPO}_{4} \cdot 6 \mathrm{H}_{2} \mathrm{O}$, is not possible since the system does not contain ammonia, therefore the impure magnesium phosphate hydrate probably contains potassium. The other phase, montgomeryite, is probably also impure.

$\mathrm{X}$-ray diffraction analysis of the ash-blowdown waste form after curing for 3 months indicated sodium phosphate hydrates, sylvine, potassium chloride, and sodium calcium sulfate. (See Appendix 3) The ash and blowdown waste react with the matrix phase magnesium potassium phosphate 6 hydrate to form the new phases which result in expansion, cracking, and sample deterioration.

Components found in Ceramicrete ${ }^{\mathrm{TM}}$ samples for the blowdown are:

$\mathrm{KMgPO}_{4} \cdot 6 \mathrm{H}_{2} \mathrm{O}$

$\mathrm{SiO}_{2}$-silicon oxide

MgO-magnesium oxide.

Components in Ceramicrete ${ }^{\mathrm{TM}}$ samples made with the SRS ash and blowdown are: $\mathrm{KMgPO}_{4} \cdot 6 \mathrm{H}_{2} \mathrm{O}$ MgO-magnesium oxide $\mathrm{Ca}_{4} \mathrm{MgAl}_{4}\left(\mathrm{PO}_{4}\right)_{6}(\mathrm{OH})_{4} \cdot 12 \mathrm{H}_{2} \mathrm{O}$-Montgomeryite 
The Ceramicrete ${ }^{\mathrm{TM}}$ blank with Coal ash components were $\mathrm{KMgPO}_{4} \cdot 6 \mathrm{H}_{2} \mathrm{O}$ and $\mathrm{SiO}_{2}$.

SEM of the Super Cement ${ }^{\mathrm{TM}}$ waste forms indicate the presence of $\mathrm{Ca}$ and $\mathrm{Si}$ which is probably from the high solids ash. X-ray diffraction analyses of Super Cement ${ }^{\mathrm{TM}}$ waste forms reveals highly amorphous characteristics with few crystalline structures but does indicate calcite which is probably contributed by the incinerator waste.

Permeability Results

Permeability testing was conducted using Permeameter Model \# K-670A purchased from ELE International in Lake Bluff, Ilinois of the non radioactive blank samples of each technology to determine the best projected permeability for each technology.

Portland Cement waste forms were prepared with 10 and $30 \mathrm{wt} \% \mathrm{NaCl}$ solution which were also analyzed. A picture of the permeameter is given in Figure 2 on the next page.

Permeability results are summarized in Table XX. The data and calculations for these permeability determinations are given in Appendix 2.

Table XII. Waste Form Permeability

Description

Ceramicrete $^{\mathrm{TM}}$ Blank

Portland Cement made with $10 \% \mathrm{NaCl}$ simulant

Portland Cement made with $30 \% \mathrm{NaCl}$ simulant

Super Cement ${ }^{\mathrm{TM}}$ Blank
Permeability $(\mathrm{cm} / \mathrm{s})$

$1 \times 10^{-4}$

$<1 \times 10^{-10}$

$.3 \times 10^{-9}$

$<1 \times 10^{-10}$ 
WSRC-TR-99-00182

June 1, 1999

Page 14 of 21

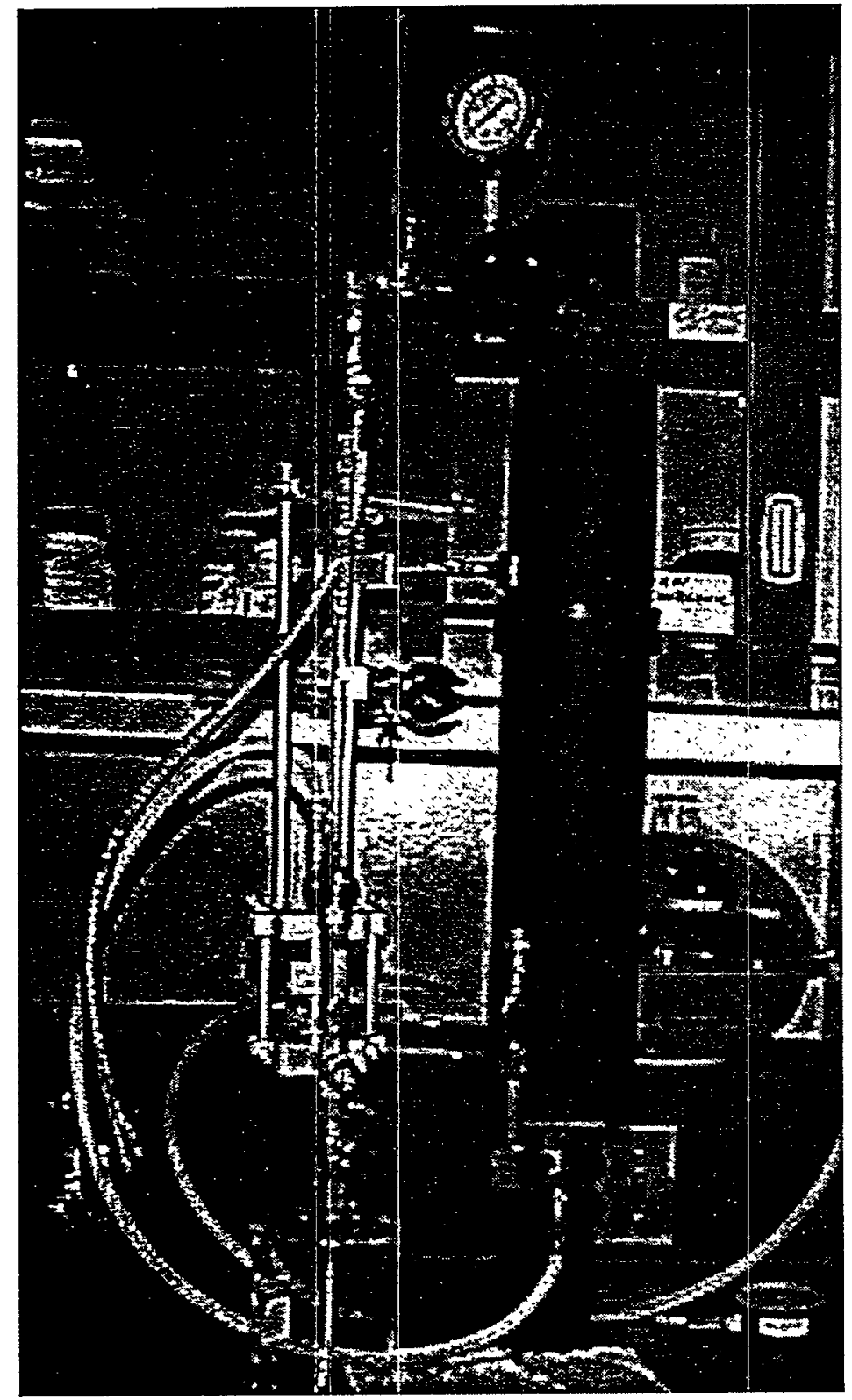

Figure 2. Permeameter manufactured by ELE 


\section{Leaching Results}

A sample of ash submitted for TCLP without solidification passed all SRS leachability limits. The following are the analytical results for SRS High Solids ash TCLP:

\begin{tabular}{llllllll}
$\mathrm{Hg}$ & $\mathrm{Ag}$ & $\mathrm{As}$ & $\mathrm{Ba}$ & $\mathrm{Cd}$ & $\mathrm{Cr}$ & $\mathrm{Pb}$ & $\mathrm{Se}$ \\
\hline $\mathrm{DL}$ & $<\mathrm{DL}$ & 0.099 & 0.243 & 0.011 & 0.046 & 0.023 & 0.032
\end{tabular}

Initially blowdown solution contained:

$\begin{array}{ll}\text { Mercury } & <.01 \mathrm{ppm} \\ \text { Silver } & <0.025 \mathrm{ppm} \\ \text { Arsenic } & 2.56 \mathrm{ppm} \\ \text { Barium } & 0.12 \mathrm{ppm} \\ \text { Cadmium } & 0.211 \mathrm{ppm} \\ \text { Chromium } & 2.11 \mathrm{ppm} \\ \text { Lead } & 0.325 \mathrm{ppm} \\ \text { Selenium } & 0.65 \mathrm{ppm}\end{array}$

Only selenium was outside SRS TCLP limits which are based on 40CFR 268.48 Universal Treatment Standards (UTS). For the eight RCRA metals the limits are: Mercury $\quad 0.025 \mathrm{ppm}$

Silver $\quad 0.3 \mathrm{ppm}$

Arsenic $\quad 5 \mathrm{ppm}$

Barium $\quad 7 \mathrm{ppm}$

Cadmium $\quad 0.69 \mathrm{ppm}$

Chromium $\quad 0.86 \mathrm{ppm}$

Lead $\quad 0.37 \mathrm{ppm}$

Selenium $\quad 0.16 \mathrm{ppm}$

Toxicity Characteristic Leaching Procedure (TCLP) results are given in Table XIII for selected representative Ceramicrete ${ }^{\mathrm{TM}}$ waste forms made with SRS incinerator waste. The concentrations of the hazardous metals in the leachate meet SRS TCLP limits. Stabilization of heavy metal contaminants is due to chemical stabilization by reactions between the contaminants and the phosphates, followed by microencapsulation of the stabilized contaminants within the waste form matrix. 
Table XIII. TCLP Results for Ceramicrete ${ }^{\mathrm{TM}}$ Waste Forms (mg/liter)

\begin{tabular}{lllllllll} 
Sample & $\mathrm{Hg}$ & $\mathrm{Ag}$ & $\mathrm{As}$ & $\mathrm{Ba}$ & $\mathrm{Cd}$ & $\mathrm{Cr}$ & $\mathrm{Pb}$ & $\mathrm{Se}$ \\
\hline 1 & $<\mathrm{DL}$ & $<\mathrm{DL}$ & .406 & $<\mathrm{DL}$ & $<\mathrm{DL}$ & .014 & $<\mathrm{DL}$ & .084 \\
2 & $<\mathrm{DL}$ & $<\mathrm{DL}$ & .082 & $<\mathrm{DL}$ & $<\mathrm{DL}$ & .115 & $<\mathrm{DL}$ & .028 \\
4 & $<\mathrm{DL}$ & $<\mathrm{DL}$ & .099 & $<\mathrm{DL}$ & $<\mathrm{DL}$ & .016 & $<\mathrm{DL}$ & $<\mathrm{DL}$ \\
5 & $<\mathrm{DL}$ & $<\mathrm{DL}$ & .067 & $<\mathrm{DL}$ & $<\mathrm{DL}$ & .016 & $<\mathrm{DL}$ & $<\mathrm{DL}$ \\
7 & $<\mathrm{DL}$ & $<\mathrm{DL}$ & .068 & $<\mathrm{DL}$ & $<\mathrm{DL}$ & .008 & $<\mathrm{DL}$ & $<\mathrm{DL}$ \\
10 & $<\mathrm{DL}$ & $<\mathrm{DL}$ & .069 & $<\mathrm{DL}$ & $<\mathrm{DL}$ & .005 & $<\mathrm{DL}$ & $<\mathrm{DL}$ \\
12 & $<\mathrm{DL}$ & $<\mathrm{DL}$ & .089 & $<\mathrm{DL}$ & $<\mathrm{DL}$ & .011 & $<\mathrm{DL}$ & .048 \\
18 & $<\mathrm{DL}$ & $<\mathrm{DL}$ & $<\mathrm{DL}$ & $<\mathrm{DL}$ & $<\mathrm{DL}$ & .025 & $<\mathrm{DL}$ & .027 \\
19 & $<\mathrm{DL}$ & $<\mathrm{DL}$ & $<\mathrm{DL}$ & $<\mathrm{DL}$ & $<\mathrm{DL}$ & .019 & $<\mathrm{DL}$ & $<\mathrm{DL}$
\end{tabular}

$<D L$ means less than the detectable limit. These limits are $\mathrm{CrDL}=.0056$, AsDL $=.045$, $\mathrm{SeDL}=.0045, \mathrm{BaDL}=.0051, \mathrm{CdDL}=.0044, \mathrm{AgDL}=.0073, \mathrm{PbDL}=.0159, \mathrm{HgDL}=.00035$

All Ceramicrete ${ }^{\mathrm{TM}}$ samples pass WAC leaching requirements for RCRA metals.

Sample 1 is a blank containing no ash or scrubber solution only coal ash. Waste forms in samples 2,4 (see matrix in Table IV) made with blowdown show a decrease in all chemical species. The selenium level in the blowdown which initially exceeded limits is within compliance after solidification. The waste forms in samples 5,7 made with SRS ash show a decrease in chemical species leaching. A decrease in leaching was also seen for samples 10,12 made with both $10 \mathrm{wt} \%$ blowdown and SRS ash and samples 18, 19 made with ash and $30 \%$ blowdown.

TCLP results are given in Table XIV. for selected representative Super Cement ${ }^{\mathrm{TM}}$ waste forms made with SRS incinerator waste. The concentrations of the hazardous metals in the leachate meet SRS requirements.

Table XIV. TCLP Results for Super Cement ${ }^{\mathrm{TM}}$ Waste Forms (mg/liter)

\begin{tabular}{lllllllll} 
Sample & $\mathrm{Hg}$ & $\mathrm{Ag}$ & $\mathrm{As}$ & $\mathrm{Ba}$ & $\mathrm{Cd}$ & $\mathrm{Cr}$ & $\mathrm{Pb}$ & $\mathrm{Se}$ \\
\hline
\end{tabular}

22

26

32

35

38

41 $\angle D L \quad \angle D L \quad \angle D L \quad .344 \quad \angle D L \quad \angle D L \quad \angle D L \quad \angle D L$

$<D L<D L \quad \angle D L \quad .172<D L \quad<D L \quad<D L \quad .039$

$\angle D L \quad \angle D L \quad \angle D L \quad .182<D L \quad \angle D L \quad \angle D L \quad \angle D L$

$<\mathrm{DL} \quad \mathrm{DL} \quad<\mathrm{DL} \quad .322 \quad<\mathrm{DL} \quad \angle \mathrm{DL} \quad<\mathrm{DL} \quad .027$

$\angle D L<D L \quad \angle D L \quad .262<D L \quad \angle D L \quad \angle D L \quad \angle D L$

$<\mathrm{DL} \quad<\mathrm{DL} \quad<\mathrm{DL} \quad .206<\mathrm{DL} \quad<\mathrm{DL} \quad .005 \quad .035$ 
All Super Cement ${ }^{\mathrm{TM}}$ Samples meet WAC leaching requirements. Super Cement ${ }^{\mathrm{TM}}$ waste form samples 22 and 26 made with scrubber solution showed a decrease in chemical species except for barium which showed an increase possibly from the Super Cement ${ }^{\mathrm{TM}}$ changing barium bound in the blowdown in a non leachable form to a leachable form.

Super Cement ${ }^{\mathrm{TM}}$ sample 32 made with only ash showed a decrease in chemical species except for barium which remained relatively constant. Samples 35,38 , and 41 made with a combination of ash and blowdown showed a leaching decrease in chemical species except for barium which showed an increase.

\section{Waste Loading Results}

The typical Portland cement plant waste loadings are $31.8 \mathrm{wt} \%$ for ash and $46.1 \mathrm{wt} \%$ for scrubber solution. Plant formulations are based on previous work performed by Don Fisher at SRS. ${ }^{4,5}$ The calculations for plant waste loadings are given in Appendix 1.

Ceramicrete ${ }^{\mathrm{TM}}$ Waste Loadings are given in Table XV.

Table XV. Ceramicrete ${ }^{\mathrm{TM}}$ Waste Loadings

$$
\mathrm{Wt} \%
$$

Sample Wt\% SRS Blowdown (BD)

Number Bd Ash Total Solids Wt \%

\begin{tabular}{|c|c|c|}
\hline 1 & 0 & 0 \\
\hline 2 & 12 & 0 \\
\hline 3 & 25.3 & 0 \\
\hline 4 & 28.0 & 0 \\
\hline 5 & 0 & 33. \\
\hline 6 & 0 & 42 \\
\hline 7 & 0 & 51 \\
\hline 8 & 0 & 43.1 \\
\hline 9 & 0 & 50.0 \\
\hline 10 & 23 & 15 \\
\hline 11 & 12.4 & 37.3 \\
\hline 12 & 13 & 40 \\
\hline 13 & 17.4 & 17.4 \\
\hline 14 & 29.2 & 5.9 \\
\hline 15 & 33.9 & 3.4 \\
\hline 16 & 32.3 & 6.5 \\
\hline 17 & 22.8 & 22.8 \\
\hline 18 & 12.8 & 38.3 \\
\hline 19 & 33.3 & 6.7 \\
\hline 20 & 30.9 & \\
\hline
\end{tabular}


Super Cement ${ }^{\mathrm{TM}}$ waste loadings are given in Table XVI.

Table XVI. Super Cement ${ }^{\mathrm{TM}}$ Waste Loadings

\begin{tabular}{llll} 
& \multicolumn{3}{c}{ Wt\% } \\
Sample & Wt\% & SRS & Blowdown (BD) \\
Number & Bd & Ash & Total Solids Wt \% \\
\hline 21 & 0 & 0 & 0 \\
22 & 39.2 & 0 & 10 \\
23 & 39.3 & 0 & 10 \\
24 & 40.3 & 0 & 20 \\
25 & 43.1 & 0 & 20 \\
26 & 40.8 & 0 & 30 \\
27 & 0 & 35.7 & 10 \\
28 & 0 & 52.9 & 0 \\
29 & 0 & 61.2 & 0 \\
30 & 0 & 66.7 & 0 \\
31 & 0 & 51.4 & 0 \\
32 & 0 & 40.4 & 0 \\
33 & 19.4 & 19.4 & 10 \\
34 & 10.6 & 31.8 & 10 \\
35 & 32.1 & 6.5 & 10 \\
36 & 21.1 & 21.1 & 20 \\
37 & 10.8 & 32.4 & 20 \\
38 & 34.6 & 7.0 & 20 \\
39 & 21.7 & 21.7 & 30 \\
40 & 27.1 & 27.1 & 30 \\
41 & 34.3 & 6.9 & 30
\end{tabular}

Notes for Tables XV and XVI:

1) $\mathrm{Wt} \% \mathrm{Bd}$ is the amount in grams of the blowdown or scrubber solution divided by the total weight of the sample that was incorporated in the waste form.

2) BD Total Solids $\mathrm{Wt} \%$ is the concentration of the blowdown or scrubber solution that was incorporated in the waste form.

Waste. loadings for Ceramicrete ${ }^{\mathrm{TM}}$ and Super Cement ${ }^{\mathrm{TM}}$ samples made with only scrubber solution were slightly less than those for the plant. Samples were made with 20 and 30 wt \% scrubber solution which is not performed at the SRS incinerator currently. These concentrations were run because an evaporator is planned as part of plant modifications. 
Higher waste loadings by weight were achievable with waste forms made with only ash for both the Ceramicrete ${ }^{\mathrm{TM}}$ and Super Cement ${ }^{\mathrm{TM}}$ technologies than that currently used by the incinerator. The waste loadings by volume conversions from waste loadings by. weight for both Super Cement ${ }^{\mathrm{TM}}$ and Ceramicrete ${ }^{\mathrm{TM}}$ will be about the same since the densities of each type of waste form are similar. The waste form densities were:

Table XVII. Waste Form Densities

Sample description

Super Cement ${ }^{\mathrm{TM}}$ and ash

Super Cement ${ }^{\mathrm{TM}}$ and scrubber solution

Ceramicrete $^{\mathrm{TM}}$ and ash

Ceramicrete $^{\mathrm{TM}}$ and scrubber solution.
Density $(\mathrm{g} / \mathrm{ml})$

1.9

1.8

1.8

1.7

\section{Conclusions}

Ceramicrete ${ }^{\mathrm{TM}}$ had high compressive strength and effectively stabilized hazardous contaminants in the high solids ash and scrubber solution (blowdown) wastes through chemical reaction and microencapsulation. Super Cement ${ }^{\mathrm{TM}}$ samples also had high compressive strength and stabilized hazardous contaminants in high solids incinerator waste.

Viscosity of the Ceramicrete ${ }^{\mathrm{TM}}$ is less than traditional Portland cement and should require less mixing torque. The viscosity of Super Cement ${ }^{\mathrm{TM}}$ samples is comparable to samples made with Portland cement. Bleed water was observed initially for both the Ceramicrete $^{\mathrm{TM}}$ and Super Cement ${ }^{\mathrm{TM}}$ made with blowdown but was absorbed after 24 hours. With waste forms made with blowdown and ash, crystallization as well as swelling seems to occur with Ceramicrete ${ }^{\mathrm{TM}}$ samples. This phenomenon does not occur with Super Cement ${ }^{\mathrm{TM}}$.

Ceramicrete $^{\mathrm{TM}}$ waste forms exhibited high compressive strength 28 days after preparation but exhibited some physical deterioration after 3 to 4 months of curing. The deterioration was caused by waste and matrix reaction which form potassium chloride, sodium potassium hydrates, and sodium calcium sulfates. The formation of these salt phases resulted in expansion and cracking of the samples. Consequently, Ceramicrete ${ }^{\mathrm{TM}}$ is not recommended for sodium chloride wastes.

Permeability of a blank made with only Ceramicrete ${ }^{\mathrm{TM}}$ and no SRS ash or blowdown (best case scenario) were in the range of $1 \times 10^{-4} \mathrm{~cm} / \mathrm{s}$ which does not meet the current SRS permeability of $10^{-8} \mathrm{~cm} / \mathrm{s}$. A blank made with Super Cement ${ }^{\mathrm{TM}}$ gave acceptable permeability measurements of $<1 \times 10^{-10} \mathrm{~cm} / \mathrm{s}$. 
The Ceramicrete ${ }^{T M}$ waste forms generated with SRS ash and blowdown passed acceptance criteria for leachability, bleed water, and compression testing but do not seem to meet the SRS permeability acceptance criteria or durability requirements.

Setting problems with the Super Cement ${ }^{\mathrm{TM}}$ waste forms made with only ash were overcome by adding calcium hydroxide or Portland cement to the ash before mixing with Super Cement ${ }^{\mathrm{TM}}$ and water.

Waste forms made with Super Cement ${ }^{\mathrm{TM}}$ meet all SRS acceptance criteria and have a higher waste loading for ash than the current Portland cement technology employed. Samples made with scrubber solution were slightly less than the waste loading of Portland cement. The actual waste loadings of blowdown waste forms for both Ceramicrete ${ }^{\mathrm{TM}}$ and Super Cement ${ }^{\mathrm{TM}}$ are actually greater than the plant waste loadings because samples in this study were concentrated up to 20 and $30 \mathrm{wt} \%$ total solids whereas the plant blowdown concentration is only $10 \mathrm{wt} \%$ total solids.

Super Cement ${ }^{\mathrm{TM}}$ is a viable alternative to the current Portland cement solidification of SRS incinerator wastes. Issues that need to be addressed before recommending Super Cement ${ }^{\mathrm{TM}}$ over the Portland cement technology are the cost of any plant modifications to use Super Cement ${ }^{\mathrm{TM}}$ technology, cost of Super Cement ${ }^{\mathrm{TM}}$, cost of new additives, and the cost (if necessary) to license the technology from ADTECHS Corp./JGC Corp. 


\section{Quality Assurance}

Quality Assurance testing was conducted in accordance with SRS procedures. Results are recorded in Laboratory Notebook WSRC-NB-96-633. The Task Technical Plan and Task Quality Assurance Plan are documented in WSRC-RP-98-01361 Rev. 0.

TCLP analyses were performed using the Toxic Characteristic Leaching Procedure EPA method 1311.

\section{Acknowledgements}

This work was done as part of the DOE Office of Science and Technology, Mixed Waste Focus Area program (TTP SR1-8-MW-44).

Westinghouse expresses thanks to Dileep Singh from Argonne National Laboratory for technical assistance during the fabrication of the Ceramicrete ${ }^{\mathrm{TM}}$ solid waste forms and to R. Kobayashi and T. Sasaki from ADTECHS Corp./JGC Corp. during the fabrication of Super Cement ${ }^{\mathrm{TM}}$ waste forms.

\section{References}

${ }^{1}$ D. Singh, A.S. Wagh, J.C. Cunnane, J.L. Mayberry, "Chemically Bonded Phosphate Ceramics for Low-Level Mixed-Waste Stabilization," J. Environ. Sci. Health, A32 (2), 527-541 (1997).

${ }^{2}$ A.D. Wilson and H.W. Nicholson, Acid-base cements, Cambridge Univ. Press (1993).

${ }^{3} 40$ CFR 268.48, Code of Federal Regulations 40, "Protection of Environment" Section 268.48.

${ }^{4}$ D.L. Fisher,1995, "CIF Blowdown Stabilization: Formula Development Report (U),"WSRC-TR-95-00114, March 9, 1995.

${ }^{5}$ D.L. Fisher,1996, "CIF Ashcrete Mixture Limits (U)," WSRC-TR-96-0169, June 14, 1996. 
SRC-TR-99-00182

June 1, 1999

Page A1-1

Appendix 1.

Waste Loadings Calculations for Portland Cement 
SRC-TR-99-00182

June 1,1999

Page A1- 2

\section{Calculations}

Comparison of waste loadings was performed by first determining the algorithm used by the plant to make Portland cement waste forms. For waste forms made with ash the algorithm is

$y=.05582 x^{4}-.51808 x^{3}+1.8576 x^{2}-3.5521 x+4.162$

Where $\mathrm{x}=$ water to ash ratio and $\mathrm{y}=$ slurry to cement ratio

This is used for $\mathrm{x}$ values greater than or equal to 1 and values less than or equal to 3.25 . Optimally the plant tries to achieve an $x$ value of 1.25 .

For our case the ash contained 25 grams of water in 100 grams of ash. Since this is not a 1.25 ratio water must be added to the ash (in this case 100 grams). Doing this gives $\mathrm{x}=$ 1.25 and using the equation we find $\mathrm{y}=1.748$.

The amount of cement needed for mixing is found by dividing the slurry weight by $y$ : 200 grams of slurry/1.748 $=114.4$ grams of Portland cement needed.

The plant typical ash waste loading is therefore

100 grams of ash $/ 314.4$ grams total mix times $100=31.8 \%$ ash

Waste Loadings for plant Portland cement made with scrubber solution uses the formulation of water/cement $=.415 / 1$.

The plant scrubber solution contains approximately $10 \%$ wt total solids. For 100 grams of scrubber solution there is 90 grams of water. The amount of cement needed would therefore be 216.9 grams for this sample. A typical plant waste loading for scrubber solution is 100 grams of scrubber solution / 216.9 grams of total mix x $100=46.1 \%$. 
Appendix 2.

\section{Permeability Calculations for Waste Forms}




\section{Calculations}

1) Ceramicrete Blank Permeability

$\mathrm{L}=$ length of sample $=.396 \mathrm{~cm}$

$\mathrm{D}=$ diameter of sample $=2.66 \mathrm{~cm}$

$\mathrm{R}=.5 \times \mathrm{D}=1.33$

$\mathrm{A}=3.14 \mathrm{r} \times \mathrm{r}=5.5836 \mathrm{~cm}^{2}$

Manometer height $1=h 1=12.5$

Manometer height $2=\mathrm{h} 2=10.2$

Average manometer height $=\mathrm{h}=(\mathrm{h} 1+\mathrm{h} 2) / 2=11.35 \mathrm{~cm}$

Pressure gauge 1 reading $=\mathrm{P} 1=10 \mathrm{psig}$

Pressure gauge 2 reading $=\mathrm{P} 2=0$ psig

$\mathrm{H}=(\mathrm{P} 1-\mathrm{P} 2) 70.31+\mathrm{h}=(10-0) 70.31+11.35=714.45$

$\mathrm{Q}=$ volume collected $/$ collection time $=54.52 \mathrm{~cm}^{3} / 60$ seconds $=.9087 \mathrm{~cm}^{3} / \mathrm{s}$

Permeability $=\mathrm{K}=\mathrm{QL} / \mathrm{AH}=(.9087)(.396) /(5.5836)(714.45)=1 \times 10^{-4} \mathrm{~cm} / \mathrm{s}$

2) Portland cement made with $10 \% \mathrm{NaCl}$ simulant Permeability

$\mathrm{L}=$ length of sample $=.793 \mathrm{~cm}$

$\mathrm{D}=$ diameter of sample $=3.075 \mathrm{~cm}$

$\mathrm{R}=.5 \times \mathrm{D}=1.54$

$\mathrm{A}=3.14 \mathrm{r} \times \mathrm{r}=7.42 \mathrm{~cm}^{2}$

Manometer height $1=\mathrm{h} 1=2 \mathrm{~cm}$

Manometer height $2=\mathrm{h} 2=3 \mathrm{~cm}$

Average manometer height $=\mathrm{h}=(\mathrm{h} 1+\mathrm{h} 2) / 2=2.5 \mathrm{~cm}$

Pressure gauge 1 reading $=\mathrm{P} 1=10 \mathrm{psig}$

Pressure gauge 2 reading $=\mathrm{P} 2=0$ psig

$\mathrm{H}=(\mathrm{P} 1-\mathrm{P} 2) 70.31+\mathrm{h}=(10-0) 70.31+2.5=705.6$

$\mathrm{Q}=$ volume collected $/$ collection time $=0 \mathrm{~cm}^{3} / 12 \times 3600$ seconds $=0 \mathrm{~cm}^{3} / \mathrm{s}$

Solve for $Q$ if $K=1 \times 10^{-10} \mathrm{~cm} / \mathrm{s}$

If Permeability $=\mathrm{K}=\mathrm{QL} / \mathrm{AH}=(\mathrm{Q})(.793) /(7.42)(705.6)=1 \times 10^{-10} \mathrm{~cm} / \mathrm{s}$

$\mathrm{Q}=.0036 \mathrm{mls} / \mathrm{hr} \quad$ (this is probably the smallest flowrate that can be detected with the permeameter therefore the permeability of the sample is less than $1 \times 10^{-10} \mathrm{~cm} / \mathrm{s}$ ) 
3) Portland cement made with $30 \% \mathrm{NaCl}$ simulant Permeability

$\mathrm{L}=$ length of sample $=.863 \mathrm{~cm}$

$\mathrm{D}=$ diameter of sample $=3: 113 \mathrm{~cm}$

$\mathrm{R}=.5 \times \mathrm{D}=1.56$

$\mathrm{A}=3.14 \mathrm{rx} \mathrm{r}=7.61 \mathrm{~cm}^{2}$

Manometer height $1=\mathrm{h} 1=1.5 \mathrm{~cm}$

Manometer height $2=\mathrm{h} 2=2.5 \mathrm{~cm}$

Average manometer height $=\mathrm{h}=(\mathrm{h} 1+\mathrm{h} 2) / 2=2 \mathrm{~cm}$

Pressure gauge 1 reading $=\mathrm{P} 1=10 \mathrm{psig}$

Pressure gauge 2 reading $=\mathrm{P} 2=0 \mathrm{psig}$

$\mathrm{H}=(\mathrm{P} 1-\mathrm{P} 2) 70.31+\mathrm{h}=(10-0) 70.31+11.35=714.45$

$\mathrm{Q}=$ volume collected $/$ collection time $=.15 \mathrm{~cm}^{3} / 2.25 \mathrm{hrs}=1.9 \times 10^{-5} \mathrm{~cm}^{3} / \mathrm{s}$

Permeability $=\mathrm{K}=\mathrm{QL} / \mathrm{AH}=\left(1.9 \times 10^{-5}\right)(.863) /(6.61)(705.1)=3 \times 10^{-9} \mathrm{~cm} / \mathrm{s}$

4) Super cement BlankPermeability

$\mathrm{L}=$ length of sample $=.568 \mathrm{~cm}$

$\mathrm{D}=$ diameter of sample $=3.13 \mathrm{~cm}$

$\mathrm{R}=.5 \times \mathrm{D}=1.57$

$\mathrm{A}=3.14 \mathrm{r} \times \mathrm{r}=7.74 \mathrm{~cm}^{2}$

Manometer height $1=\mathrm{h} 1=2.1 \mathrm{~cm}$

Manometer height 2 $=\mathrm{h} 2=2.3 \mathrm{~cm}$

Average manometer height $=h=(h 1+h 2) / 2=2.2 \mathrm{~cm}$

Pressure gauge 1 reading $=\mathrm{P} 1=10 \mathrm{psig}$

Pressure gauge 2 reading $=\mathrm{P} 2=0 \mathrm{psig}$

$\mathrm{H}=(\mathrm{P} 1-\mathrm{P} 2) 70.31+\mathrm{h}=(10-0) 70.31+2.2=705.3$

$\mathrm{Q}=$ volume collected $/$ collection time $=0 \mathrm{~cm}^{3} / 12 \times 3600$ seconds $=0 \mathrm{~cm}^{3} / \mathrm{s}$

Solve for $Q$ if $K=1 \times 10^{-10} \mathrm{~cm} / \mathrm{s}$

If Permeability $=\mathrm{K}=\mathrm{QL} / \mathrm{AH}=(\mathrm{Q})(.568) /(7.74)(705.3)=1 \times 10^{-10} \mathrm{~cm} / \mathrm{s}$

$\mathrm{Q}=.0035 \mathrm{mls} / \mathrm{hr} \quad$ (this is probably the smallest flowrate that can be detected with the permeameter therefore the permeability of the sample is less than $1 \times 10^{-10} \mathrm{~cm} / \mathrm{s}$ ) 
SRC-TR-99-00182

June 1;1999

Page A3 -1

\section{Appendix 3.}

Ceramicrete $^{\mathrm{TM}}$ Ash and Blowdown Waste Form XRD 


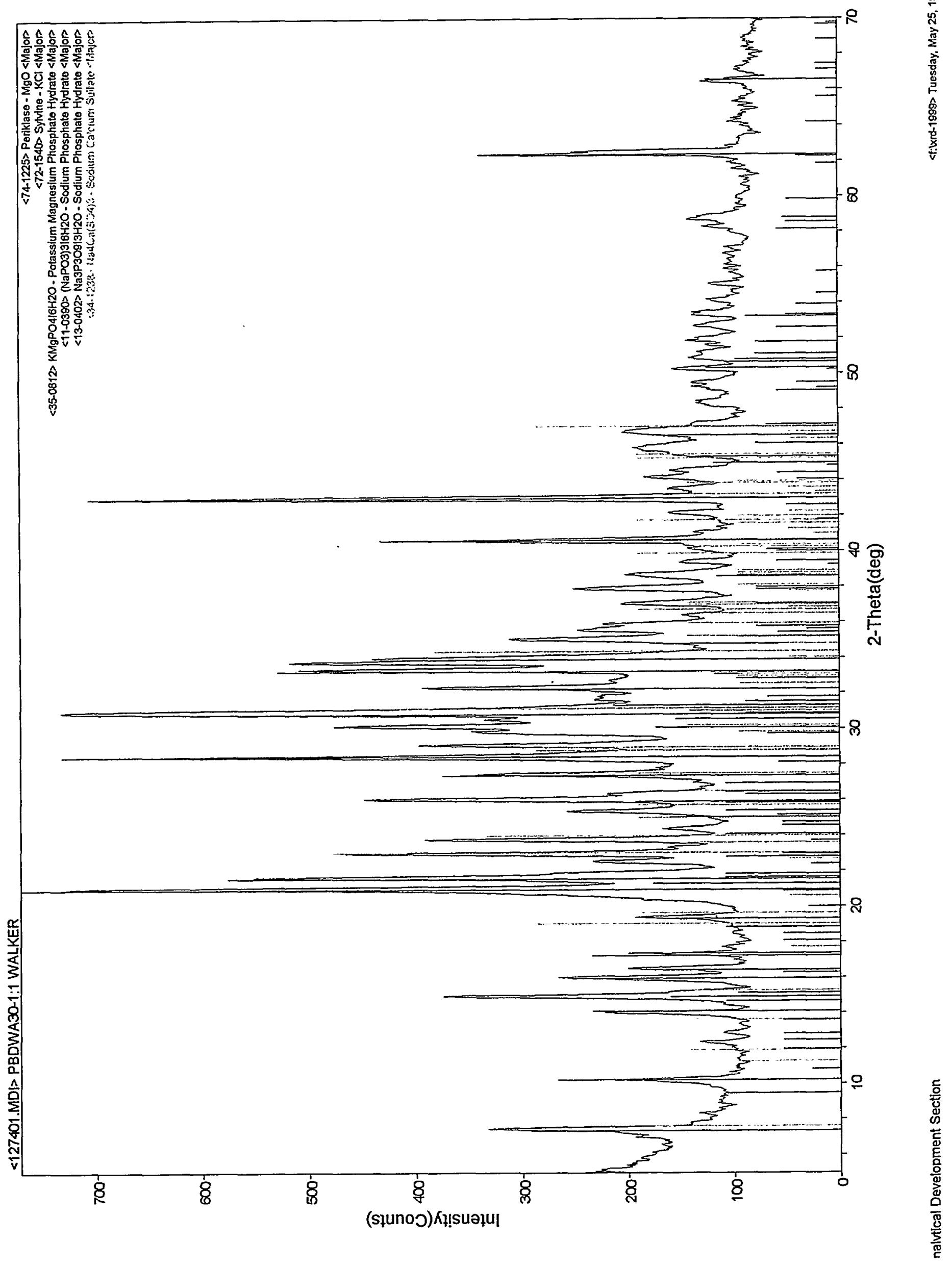




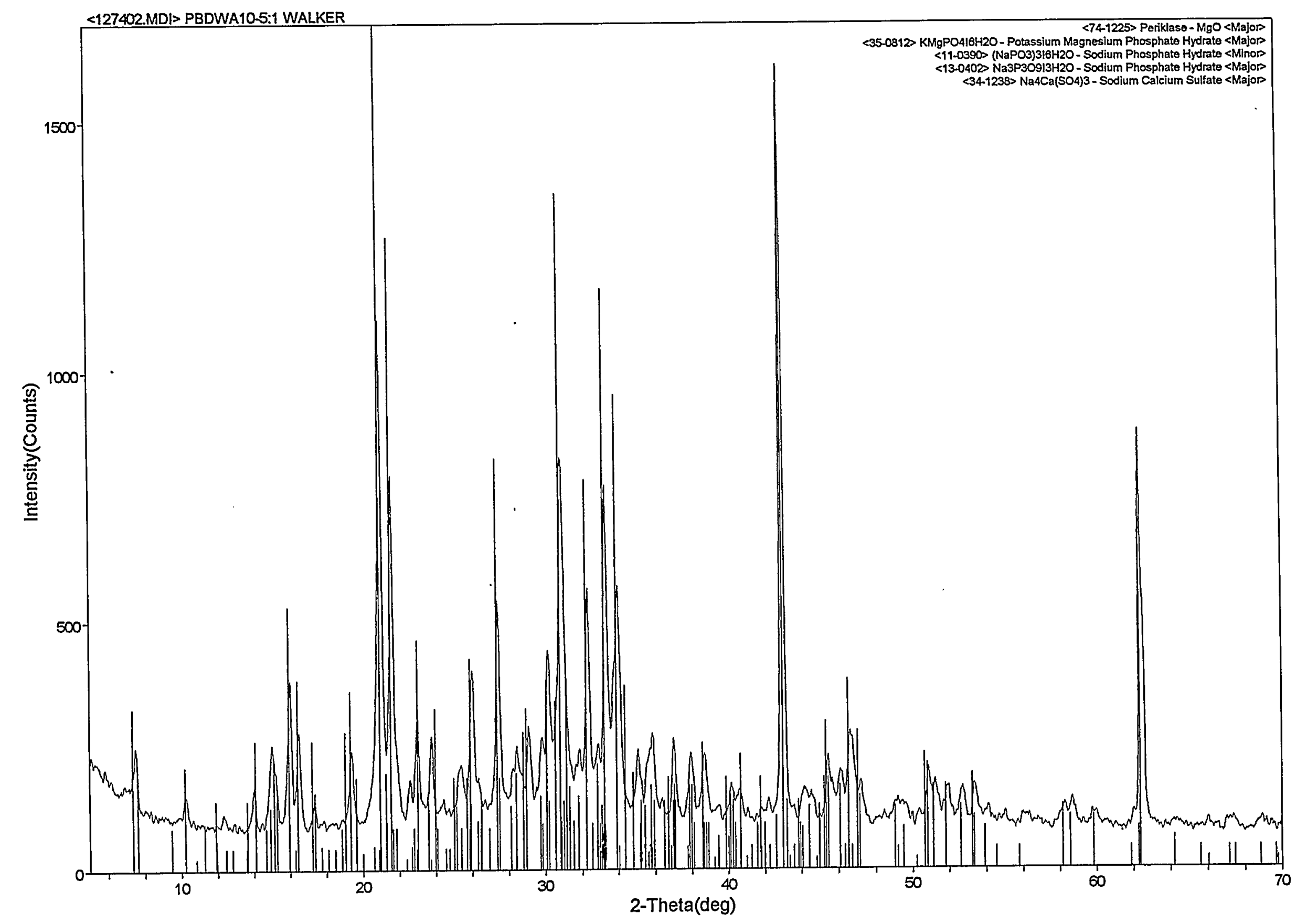

